Check for updates

Cite this: RSC Adv., 2018, 8, 24376

Received 31st May 2018

Accepted 19th June 2018

DOI: $10.1039 / c 8 r a 04640 a$

rsc.li/rsc-advances

\section{Design, synthesis and pharmacological evaluation of novel 2-chloro-3-(1H-benzo[d]imidazol-2-yl) quinoline derivatives as antitumor agents: in vitro and in vivo antitumor activity, cell cycle arrest and apoptotic response $\uparrow$}

\author{
Wen-Bin Kuang, ${ }^{\text {ab }}$ Ri-Zhen Huang, ${ }^{c}$ Yi-Lin Fang, ${ }^{\mathrm{b}}$ Gui-Bin Liang, ${ }^{\mathrm{b}}$ Chen-Hui Yang, ${ }^{\mathrm{a}}$ \\ Xian-Li Ma*a and Ye Zhang (D)*abd
}

\begin{abstract}
A series of novel 2-chloro-3-( $1 \mathrm{H}$-benzo[d] imidazol-2-yl)quinoline derivatives $\left(3 \mathrm{a}_{1}-3 \mathrm{~d}_{6}\right)$ were designed and synthesized as antitumor agents. In vitro antitumor assay results showed that some compounds exhibited moderate to high inhibitory activities against HepG2, SK-OV-3, NCl-H460 and BEL-7404 tumor cell lines, and most compounds exhibited much lower cytotoxicities against HL-7702 normal cell line compared to 5-FU and cisplatin. In vivo antitumor assay results showed that the representative compound $3 \mathrm{a}_{1}$ exhibited effective inhibition on tumor growth in the HepG2 xenograft mouse model. Mechanistic studies suggested that $3 \mathrm{a}_{1}$ may exert antitumor activity by the up-regulation of Bax, intracellular $\mathrm{Ca}^{2+}$ release, $\mathrm{ROS}$ generation, p21, p27 and p53, downregulation of $\mathrm{Bcl}-2$, activation of caspase-9 and caspase-3 and subsequent cleavage of PARP, and inhibition of CDK activity.
\end{abstract}

\section{Introduction}

As one of the second leading causes of mortality, cancer is a great concern to mankind. Due to negative lifestyle and food habits, which seriously increase the cancer risk, more and more people around the globe are diagnosed with this disease., ${ }^{1,2}$ Therefore, the discovery and development of promising new antitumor agents with high efficiency and low toxicity to healthy cells and tissues have become urgent and key focuses of pharmaceutical chemists worldwide. To realize this goal, a great deal of attention is being focused on molecules that act synchronously on multiple targets by combining two/more active pharmacophores covalently in a single-hybrid molecule with dual/multiple antitumor effects. ${ }^{3,4}$ This combination principle strategy encouraged us to design, synthesize and evaluate a new set of hybrid molecules by combining two pharmacophores

${ }^{a}$ School of Pharmacy, Guilin Medical University, North Ring 2nd Road 109, Guilin 541004, PR China. E-mail: zhangye81@126.com; mxl78@glmc.edu.cn; Fax: +86773-5895132; Tel: +86-773-5895132

${ }^{b}$ State Key Laboratory for the Chemistry and Molecular Engineering of Medicinal Resources (Ministry of Education of China), School of Chemistry and Pharmaceutical Sciences of Guangxi Normal University, Guilin 541004, PR China

${ }^{c}$ Department of Pharmaceutical Engineering, School of Chemistry and Chemical Engineering, Southeast University, Nanjing 211189, PR China

${ }^{d}$ Department of Chemistry \& Pharmaceutical Science, Guilin Normal College, Guangxi 541001, PR China

$\dagger$ Electronic supplementary information (ESI) available: The procedures for biological assays, ${ }^{1} \mathrm{H}$ NMR, ${ }^{13} \mathrm{C}$ NMR and HR-MS. See DOI: 10.1039/c8ra04640a present in a number of natural and synthetic agents: chloroquinoline and benzimidazole.

Quinoline and its derivatives display a variety of powerful biological activities including inhibition of cellular proliferation and developmental changes, ${ }^{5-7}$ which make the quinoline ring a valuable versatile synthetic scaffold for new antitumor agents. Among the various existing active scaffolds of quinolines, chloroquinoline is a type of alkaloid, which is as abundant as quinoline. Previous studies have indicated that chloroquinoline derivatives display preferable biological activities such as anticancer and antiproliferation activities., ${ }^{8,9}$ Chloroquinoline scaffold is thus chosen in the present study as an active antitumor pharmacy core, and some structural modifications are designed to explore the antitumor activity. In addition, a bicyclic compound, namely, benzimidazole, which is the fusion of benzene and imidazole, is a pharmacophore possessing a wide range of biological activities. ${ }^{10}$ Some benzimidazole derivatives have been found to display potent antitumor activities. ${ }^{11-13}$ Accordingly, the benzimidazole nucleus has been considered as an important pharmacophore in antitumor chemistry. It is thus expected that combining the chloroquinolone scaffold with the benzimidazole skeleton may lead to potent antitumor activity. Therefore, under the combination principle, a set of 2-chloroquinoline-benzimidazole derivatives $\mathbf{3}\left(\mathbf{3 a}_{\mathbf{1}}-\mathbf{3 d}_{\mathbf{6}}\right)$ were synthesized, and their antitumor activities were evaluated. Moreover, previous studies have indicated that both quinoline and benzimidazole derivatives exert antitumor activities through modulation of cell cycle arrest and apoptotic 
responses. ${ }^{14-16}$ Therefore, mechanistic studies focused on apoptosis and cycle arrest induced by the representative compound $3 \mathbf{a}_{\mathbf{1}}$ were also performed.

\section{Results and discussion}

\subsection{Chemistry}

2-Chloro-3-(1H-benzo[ $d]$ imidazol-2-yl)quinoline derivatives $\mathbf{3}\left(\mathbf{3 a}_{\mathbf{1}}-\mathbf{3} \mathbf{d}_{\mathbf{6}}\right)$ were synthesized as shown in Scheme 1. First, 2chloro-quinoline-3-carbaldehyde derivatives $\mathbf{2 ( 2 a - 2 d )}$ were synthesized through the Vilsmeier-Haack-Arnold reaction, which involves the combination of acetanilide derivatives $\mathbf{1}(\mathbf{1 a}-\mathbf{1 d})$ with $N, N$-dimethylformamide (DMF) in the presence of phosphorus oxychloride. ${ }^{15}$ 2-Chloro-quinoline-3benzimidazole derivatives $\mathbf{3}\left(\mathbf{3 a}_{\mathbf{1}}-\mathbf{3} \mathbf{d}_{\mathbf{6}}\right)$ were then obtained in moderate yields by the condensation reactions of $2(2 \mathbf{a}-2 d)$ with $o$-phenylenediamine derivatives in the presence of methanol. The structures of compounds $\mathbf{3}\left(\mathbf{3 a}_{\mathbf{1}}-\mathbf{3} \mathbf{d}_{\mathbf{6}}\right)$ were confirmed using various spectroscopic methods including ${ }^{1} \mathrm{H}$ NMR, ${ }^{13} \mathrm{C}$ NMR and high-resolution mass spectrometry (HR-MS) (Part 2 of ESI $\dagger$ ). In ${ }^{1} \mathrm{H}$ NMR spectra, the hydrogen of $\mathrm{NH}$ fused in benzimidazole and the aromatic hydrogens ( $\mathrm{H}-\mathrm{Ar})$ in quinolone and benzimidazole were identified by chemical shifts $(\delta)$ 12.6613.26 and 7.14-8.79, respectively. In addition, the hydrogens of methyl groups were also identified at $\delta 3.93,3.84,2.54$ and 2.34, whereas the hydrogens of $\mathrm{O}-\mathrm{CH}_{2}-\mathrm{O}$ group were found around $\delta$ 6.30. In ${ }^{13} \mathrm{C}$ NMR spectra, carbons in carbonyl and $\mathrm{O}-\mathrm{CH}_{2}-\mathrm{O}$ groups were identified at $\delta$ 161.04-161.99 and around 95.40, respectively, whereas the carbons of methyl groups were found at $\delta$ 20.59-20.94 and 55.94-56.09. The signals $(\delta)$ at 99.47148.19 were assigned to carbons in $\mathrm{C}=\mathrm{C}$ and $\mathrm{C}=\mathrm{N}$ groups as well as the aromatic carbons in quinolone and benzimidazole. HR-MS provided exact formula weights and compositions of $\mathbf{3}\left(\mathbf{3} \mathbf{a}_{\mathbf{1}}-\mathbf{3} \mathbf{d}_{\mathbf{6}}\right)$, which were well consistent with the results of ${ }^{1} \mathrm{H}$ NMR and ${ }^{13} \mathrm{C}$ NMR and the structures shown in Scheme 1 , thus indicating that the structures of compounds $\mathbf{3}\left(\mathbf{3} \mathbf{a}_{\mathbf{1}}-\mathbf{3} \mathbf{d}_{\mathbf{6}}\right)$ were confirmed.

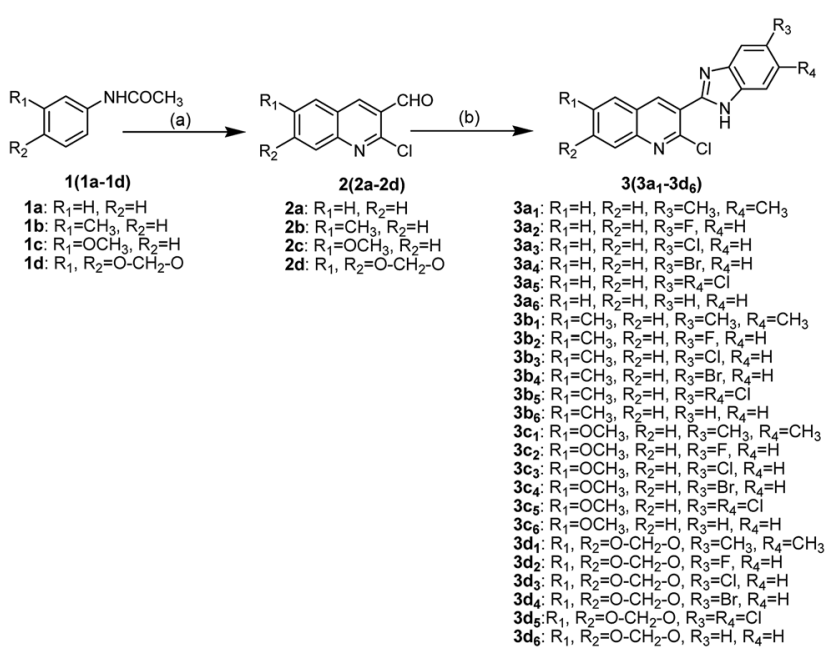

Scheme 1 Synthetic routes of compounds $3\left(3 a_{1}-3 d_{6}\right)$. Reagents and conditions: (a) $\mathrm{POCl}_{3}, \mathrm{DMF}$; (b) o-phenylenediamine derivatives, methanol.

\subsection{In vitro antiproliferative activity}

The in vitro antiproliferative activities of the compounds $\mathbf{3}\left(\mathbf{3 a}_{\mathbf{1}}-\mathbf{3} \mathbf{d}_{\mathbf{6}}\right)$ were evaluated against HepG2 (human liver cancer cells), SK-OV-3 (human ovarian cancer cells), NCI-H460 (human large cell lung cancer cells), BEL-7404 (human liver cancer cells) and HL-7702 (human liver normal cells) cell lines, using the methylthiazol tetrazolium (MTT) assay. ${ }^{15,17}$ Two commercial anticancer drugs 5-fluorouracil (5-FU) and cisplatin were used as positive controls. The results are shown in Table 1 . Table 1 indicates that many compounds showed evident antiproliferative activities against HepG2, SKOV3, NCI-H460 and BEL-7404 cell lines, and some displayed better antiproliferative activities than 5-FU and cisplatin while exhibiting lower cytotoxicities against the HL-7702 normal cell line. In the HepG2 cell line assay, compounds $\mathbf{3} \mathbf{a}_{1}, \mathbf{3} \mathbf{a}_{3}, \mathbf{3} \mathbf{a}_{4}, \mathbf{3} \mathbf{a}_{5}, \mathbf{3} \mathbf{c}_{3}, \mathbf{3} \mathbf{c}_{\mathbf{4}}, \mathbf{3} \mathbf{c}_{5}$ and $3 \mathbf{c}_{6}$ exhibited higher antiproliferative activities than 5 -FU $\left(\mathrm{IC}_{50}\right.$ $=31.98 \mu \mathrm{M}$ ), with $\mathrm{IC}_{50}$ values in the range of 7.54-28.24 $\mu \mathrm{M}$. Compounds $\mathbf{3} \mathbf{a}_{\mathbf{1}}$ and $\mathbf{3} \mathbf{a}_{5}$ exhibited better antiproliferative activities than cisplatin $\left(\mathrm{IC}_{50}=10.12 \mu \mathrm{M}\right)$. In the SKOV-3 cell line assay, compounds $\mathbf{3} \mathbf{a}_{1}, \mathbf{3} \mathbf{a}_{3}, \mathbf{3} \mathbf{a}_{5}, \mathbf{3} \mathbf{c}_{3}, \mathbf{3} \mathbf{c}_{\mathbf{5}}$ and $\mathbf{3} \mathbf{c}_{6}$ showed higher antiproliferative activities than 5 -FU $\left(\mathrm{IC}_{50}=26.34 \mu \mathrm{M}\right)$, with $\mathrm{IC}_{50}$ in the range of 8.83-23.00 $\mu \mathrm{M}$. Compounds $3 \mathrm{a}_{1}, \mathbf{3} \mathbf{a}_{3}$ and $\mathbf{3 c}_{\mathbf{3}}$ displayed better antiproliferative activities than cisplatin $\left(\mathrm{IC}_{50}=15.60 \mu \mathrm{M}\right)$. In the NCI-H460 cell line assay, compounds $3 \mathbf{a}_{1}, \mathbf{3} \mathbf{a}_{3}, \mathbf{3} \mathbf{a}_{4}, \mathbf{3} \mathbf{a}_{5}, \mathbf{3} \mathbf{c}_{1}, \mathbf{3} \mathbf{c}_{3}, \mathbf{3} \mathbf{c}_{\mathbf{4}}$ and $\mathbf{3} \mathbf{c}_{5}$ showed higher antiproliferative activities than 5 -FU $\left(\mathrm{IC}_{50}=45.44 \mu \mathrm{M}\right)$, with $\mathrm{IC}_{50}$ in the range of 14.03-38.25 $\mu \mathrm{M}$. Compounds $3 \mathrm{a}_{1}$ and $3 \mathbf{a}_{5}$ displayed higher antiproliferative activities than cisplatin $\left(\mathrm{IC}_{50}=20.36 \mu \mathrm{M}\right)$. In the BEL-7404 cell line assay, compounds $\mathbf{3} \mathbf{a}_{1}, \mathbf{3} \mathbf{a}_{3}, \mathbf{3} \mathbf{a}_{4}, \mathbf{3} \mathbf{a}_{5}, \mathbf{3} c_{1}, \mathbf{3} \mathbf{c}_{3}, \mathbf{3} \mathbf{c}_{4}, \mathbf{3} c_{5}$ and $\mathbf{3} \mathbf{c}_{6}$ exhibited higher antiproliferative activities than 5 -FU $\left(\mathrm{IC}_{50}=40.21 \mu \mathrm{M}\right)$, with $\mathrm{IC}_{50}$ values in the range of 9.06-39.94 $\mu \mathrm{M}$. The compound $3 \mathbf{c}_{\mathbf{4}}$ exhibited higher antiproliferative activity than cisplatin $\left(\mathrm{IC}_{50}=\right.$ $14.72 \mu \mathrm{M})$. Based on the antiproliferation results shown in Table 1 , it can be concluded that for compounds $\mathbf{3}\left(\mathbf{3} \mathbf{a}_{\mathbf{1}}-\mathbf{3} \mathbf{d}_{\mathbf{6}}\right)$, the absence of substitution and the methoxy substitution at 6 position of quinolone moiety as well as dimethyl, chloro and bromo substitutions in the benzimidazole moiety had positive effects on the antiproliferative activity.

Among the compounds $\mathbf{3}\left(\mathbf{3 a}_{\mathbf{1}}-\mathbf{3} \mathbf{d}_{\mathbf{6}}\right)$, the compound $\mathbf{3} \mathbf{a}_{\mathbf{1}}$ showed the best potential antiproliferative activity against these cancer cell lines. Thus, $\mathbf{3} \mathbf{a}_{\mathbf{1}}$ was selected as a representative compound for in vivo antiproliferative activity and mechanistic studies.

\subsection{Preliminary safety evaluation of $3 \mathbf{a}_{1}$}

The in vivo toxicity of compound $\mathbf{3} \mathbf{a}_{\mathbf{1}}$ was evaluated in Kun-ming (KM) mice. Through intraperitoneal injection, the mice received $3 \mathbf{a}_{\mathbf{1}}$ (dissolved in $5 \% \mathrm{v} / \mathrm{v}$ DMSO/saline solvent) at a dose of $50 \mathrm{mg}$ $\mathrm{kg}^{-1}$ per day for 8 consecutive days; then, for the next 6 days, the mice were treated with compound $\mathbf{3} \mathbf{a}_{\mathbf{1}}$ at the same dose once every two days. The body weights of the animals were monitored daily and used as a parameter of systemic toxicity.

No adverse effects were observed in the KM mice injected with $3 \mathbf{a}_{1}$ during the 14 day monitoring period. As shown in Fig. 1, the average body weights of the mice treated with $\mathbf{3} \mathbf{a}_{\mathbf{1}}$ showed similar growth rates to those of the control group. It is also worth noting 
Table $1{ }^{\alpha} C_{50}$ values of compounds $3\left(3 a_{1}-3 d_{6}\right)$ toward four selected tumor cell lines and a normal cell line ${ }^{a}$

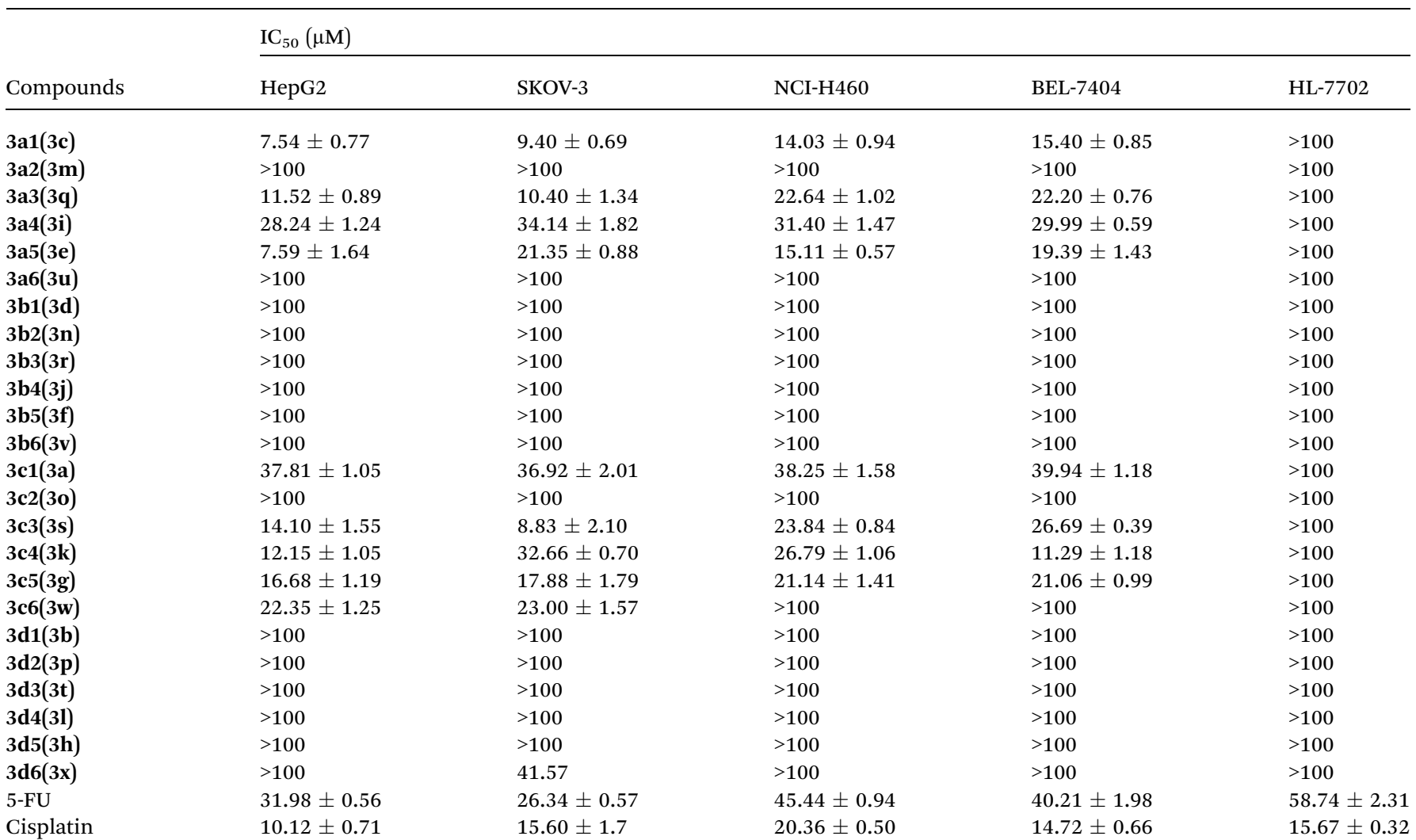

${ }^{a}{ }^{\alpha} \mathrm{IC}_{50}$ values are presented as mean $\pm \mathrm{SD}$ (standard error of the mean) from three repeated experiments.

that, as shown in Fig. 1, the injection of $\mathbf{3} \mathbf{a}_{\mathbf{1}}$ even led to extra weight gain in the KM mice, indicating that no adverse effects were found after the treatment of these mice with $\mathbf{3} \mathbf{a}_{\mathbf{1}}$.

\subsection{In vivo antiproliferative activity of $3 \mathrm{a}_{1}$}

The potential in vitro antiproliferative activity and the absence of adverse effect of $3 \mathbf{a}_{\mathbf{1}}$ encouraged us to perform in vivo antiproliferative assays to further evaluate its antitumor activity. The HepG2 xenograft model was selected in this study, and paclitaxel was used as the positive control. SPF BALB/c nude mice were

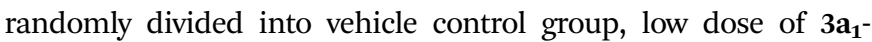
treated group, high dose of $\mathbf{3} \mathbf{a}_{\mathbf{1}}$-treated group, and positive control group. The mice in the vehicle control group were injected with $5 \%$ DMSO saline solution, and the mice in low and high dose of $\mathbf{3} \mathbf{a}_{\mathbf{1}}$ treated group were injected with $\mathbf{3} \mathbf{a}_{\mathbf{1}}$ (in $5 \%$ DMSO saline solution), whereas the mice in the positive control group were injected with paclitaxel (in 5\% DMSO saline solution). Tumor size of mice was tested twice in a week in two dimensions, and the volume was measured to evaluate in vivo antitumor activity.

As shown in Fig. 2, compared with the observations for control, the treatment with $\mathbf{3} \mathbf{a}_{\mathbf{1}}$ and paclitaxel significantly inhibited the increase in the tumour volume in mice, indicating that compound $\mathbf{3} \mathbf{a}_{\mathbf{1}}$ exhibited potential antitumor effect. The treatment of high dose of $3 \mathbf{a}_{\mathbf{1}}\left(20 \mathrm{mg} \mathrm{kg}^{-1}\right)$ exhibited similar inhibition effect on the tumour volume as that of paclitaxel $\left(5 \mathrm{mg} \mathrm{kg}{ }^{-1}\right)$. The T/C values of $3 \mathbf{a}_{\mathbf{1}}$ injected in low $\left(10 \mathrm{mg} \mathrm{kg}^{-1}\right)$ and high doses $\left(20 \mathrm{mg} \mathrm{kg}^{-1}\right)$ were determined to be $31.3 \%$ and $19.5 \%(p<0.01)$, respectively, at day 41 . Paclitaxel at the $5 \mathrm{mg}$ $\mathrm{kg}^{-1}$ dose showed a T/C value of $19.0 \%$, which was almost equal to that of $\mathbf{3} \mathbf{a}_{\mathbf{1}}$ at $20 \mathrm{mg} \mathrm{kg}^{-1}$ dose; the result indicated that $\mathbf{3} \mathbf{a}_{\mathbf{1}}$ (at $20 \mathrm{mg} \mathrm{kg}^{-1}$ dose) showed almost equal in vivo antitumor activity with paclitaxel (at $5 \mathrm{mg} \mathrm{kg}^{-1}$ dose) in the HepG2 mouse model. In addition, no evident changes in the body weight and no other adverse effects were found in the mice treated with $\mathbf{3} \mathbf{a}_{\mathbf{1}}$ (at $20 \mathrm{mg}$ $\mathrm{kg}^{-1}$ dose) (Fig. S1-1†), suggesting that $3 \mathbf{a}_{1}$ may be a good candidate for an antitumor agent.

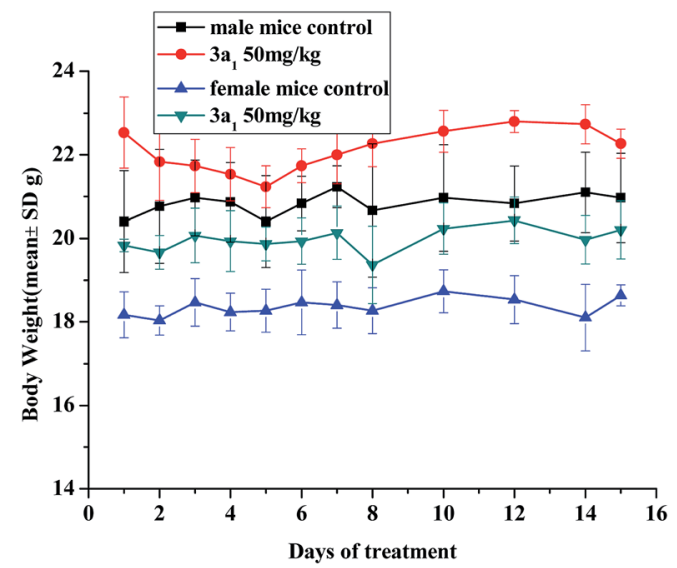

Fig. 1 Changes in the body weight of KM mice injected with compound $3 a_{1}$. There are six mice in each experimental group. 

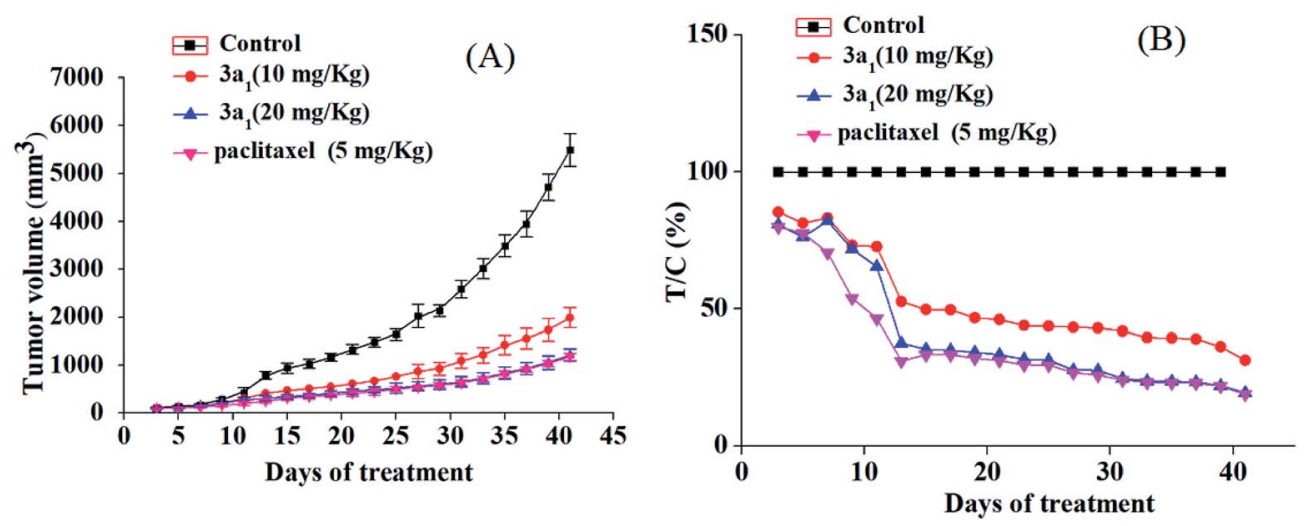

Fig. 2 In vivo anticancer activity of $3 \mathrm{a}_{1}$ in the HepG2 xenograft model. Effect of $3 \mathrm{a}_{1}$ (at doses of 10 and $20 \mathrm{mg} \mathrm{kg}^{-1}$ ), paclitaxel (at dose of $5 \mathrm{mg}$ $\mathrm{kg}^{-1}$ ) and vehicle control (5\% DMSO in saline, v/v) on tumor growth. Tumor growth was monitored by mean tumor volume $\left(\mathrm{mm}^{3}\right) \pm \mathrm{SD}(n=6)(\mathrm{A})$ and calculated as relative tumor increment rate (T/C, \%) (B).

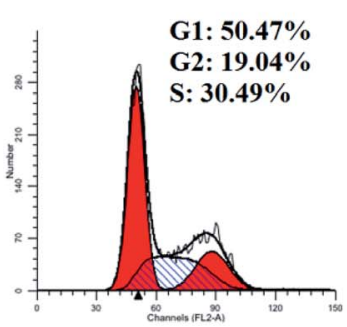

(a)

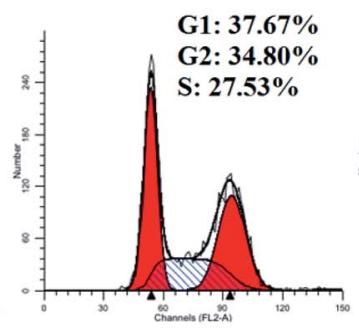

(b)

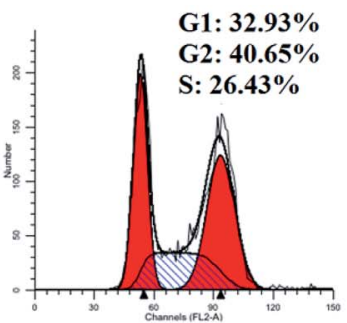

(c)

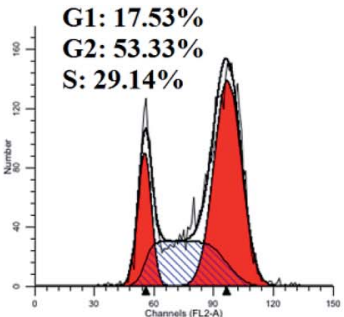

(d)

Fig. 3 Cell cycle analysis of HepG2 cells treated with $3 a_{1}$. The HepG2 cells were treated with compound $3 a_{1}$ at different concentrations, i.e., (a) $0 \mu \mathrm{M}$, (b) $6 \mu \mathrm{M}$, (c) $8 \mu \mathrm{M}$ and (d) $10 \mu \mathrm{M}$ for $48 \mathrm{~h}$.
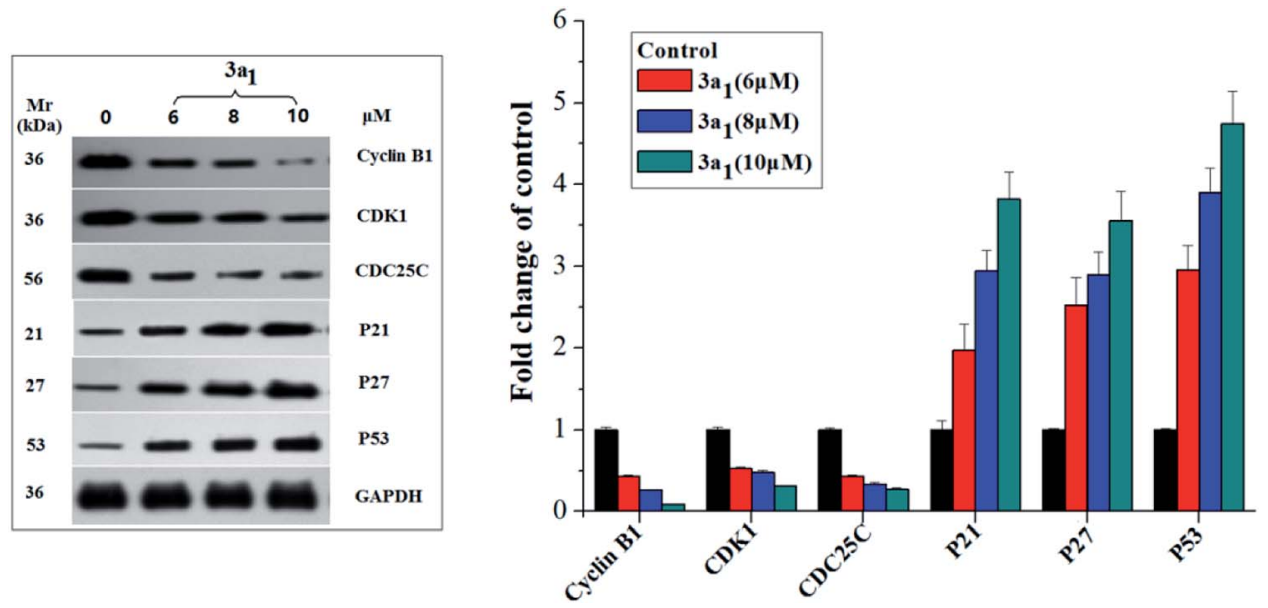

Fig. 4 Effects of compounds $3 a_{1}$ on the expression levels of relevant proteins in HepG2 cells. western blot analysis was performed with antibodies against cyclin B1, CDK1, CDC25C, p21, p23, and p53. Glyceraldehyde-3-phosphate dehydrogenase (GAPDH) was used as the loading standard.

\subsection{Study on cell cycle distribution}

As significant control mechanisms, cell cycle checkpoints control and ensure the generation and performance of cell cycle events. ${ }^{18}$ To study the potential role of cell cycle arrest in tumor cell death induced by compounds 3 , HepG2 cells were treated with the representative compound $\mathbf{3} \mathbf{a}_{\mathbf{1}}$ at different concentrations $(0,6,8$ and $10 \mu \mathrm{M})$ for $48 \mathrm{~h}$. As shown in Fig. 3, the treatment of HepG2 cells with $\mathbf{3} \mathbf{a}_{\mathbf{1}}$ promoted cell cycle arrest at the $\mathrm{G}_{2}$ phase, which led to a clear increase in the $\mathrm{G}_{2}$-phase population $(34.80 \%$ at $6 \mu \mathrm{M}, 40.65 \%$ at $8 \mu \mathrm{M}$ and $53.33 \%$ at 10 $\mu \mathrm{M})$ compared with the observations in the control group $(19.04 \%)$. Consequently, the $\mathrm{G}_{1}$-phase and S-phase populations of the HepG2 cells decreased. The results indicated that compound $3 \mathbf{a}_{1}$ clearly arrested the cell cycle of HepG2 cells at the $\mathrm{G}_{2} / \mathrm{M}$ stage in a concentration-dependent manner. 

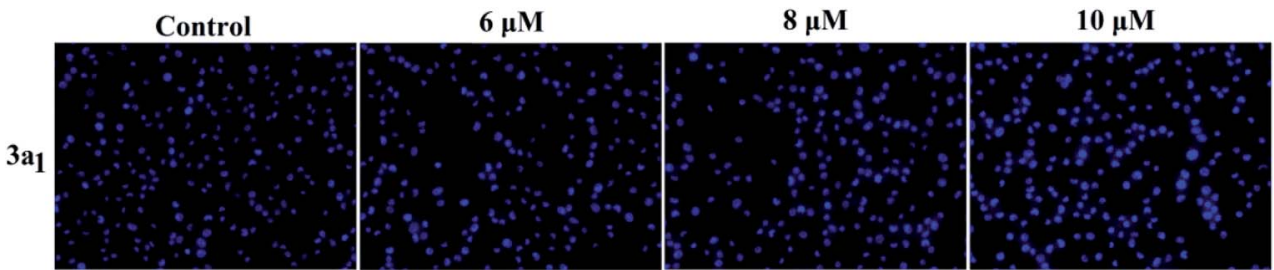

Fig. 5 Effects of the compound $3 a_{1}$ on the morphology of HepG2 cells. The cells were stained with the Hoechst 33258 dye.

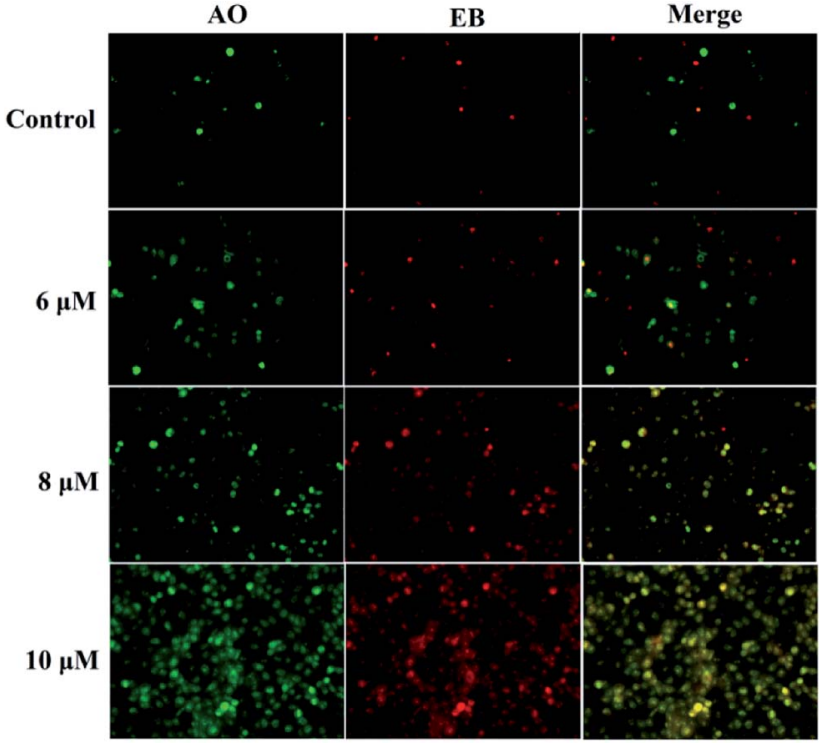

Fig. 6 Compound $3 \mathrm{a}_{1}$ induced apoptosis in HepG2 cells. The cells were visualized via $\mathrm{AO} / \mathrm{EB}$ staining coupled with fluorescence microscopy.

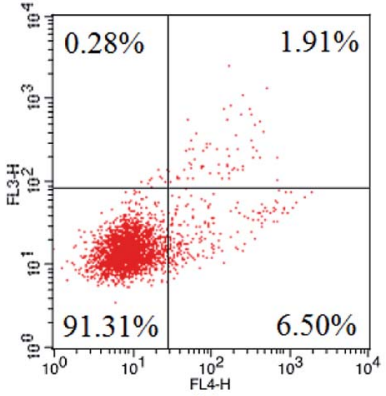

(a)

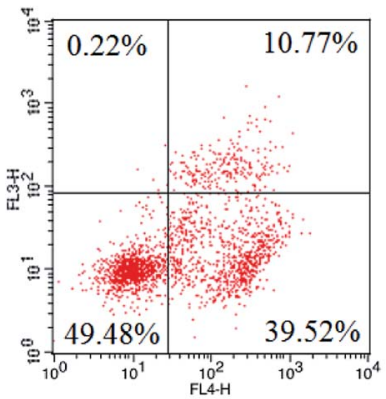

(c)

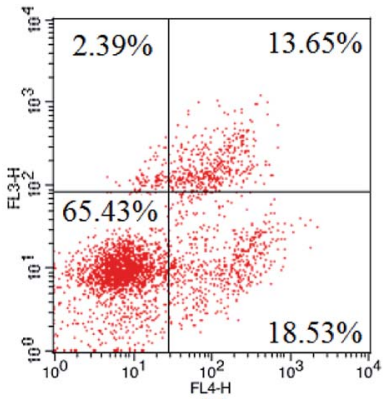

(b)

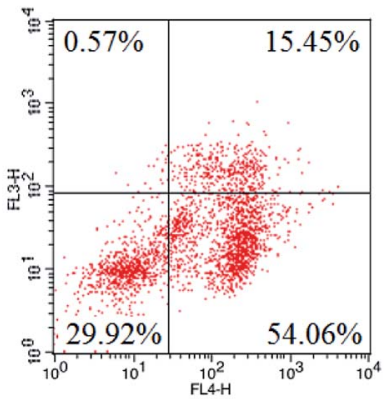

(d)
Fig. 7 Apoptosis ratios of HepG2 cells. (a) Negative control, (b) treated with $6 \mu M 3 a_{1}$, (c) treated with $8 \mu M 3 a_{1}$, (d) treated with $10 \mu M 3 a_{1}$. The cells were analyzed using the Annexin V/PI assay in a flow cytometer.
Cyclin B1/CDK1(CDC2) kinase complexes are main regulators of $\mathrm{G}_{2} / \mathrm{M}$ transition, and their generation is usually monitored by the positive mediator cell division cyclin 25 homolog $\mathrm{C}$ (CDC25C) phosphatase. ${ }^{19,20} \mathrm{CDC} 25 \mathrm{C}$ mediates the phosphorylation of CDK1 and consequently leads to the activation of cyclin B1/CDK1 complexes and execution of $\mathrm{G}_{2} / \mathrm{M}$ transition; ${ }^{19,20}$ phosphorylation of CDC25C accompanied by DNA damage and cellular activities resulting in $\mathrm{G}_{2} / \mathrm{M}$ arrest causes its degradation and sequestration to the cytoplasm, which consequently leads to the destabilization of the cyclin-CDK complexes. ${ }^{21}$ The p53, p27 and p21 genes encoded by some antioncogenes are also involved in the $\mathrm{G}_{2} / \mathrm{M}$ arrest through increasing the accumulation of the dormant cyclin B-CDK complex. ${ }^{22}$ Therefore, in the present study, the expression levels of cyclin B1, CDK1, CDC25C, p53, p27 and p21 in the HepG2 cells were assayed using western blot. As shown in Fig. 4, compared to the observations for the control, the lysates of the HepG2 cells treated with $\mathbf{3} \mathbf{a}_{\mathbf{1}}$ down-regulated the levels of cyclin B1, CDK1 and CDC25C while up-regulating the levels of p53, p21 and p27. Thus, compound $3 \mathbf{a}_{1}$ induced $\mathrm{G}_{2} / \mathbf{M}$ phase cell cycle arrest through inhibition of CDK activity and increase in the expression levels of p53, p27 and p21.

\subsection{Apoptosis assays}

Apoptosis is another important mechanism in cancer treatment, and it is a key pathway leading to cell death. ${ }^{23,24}$ Thus, the

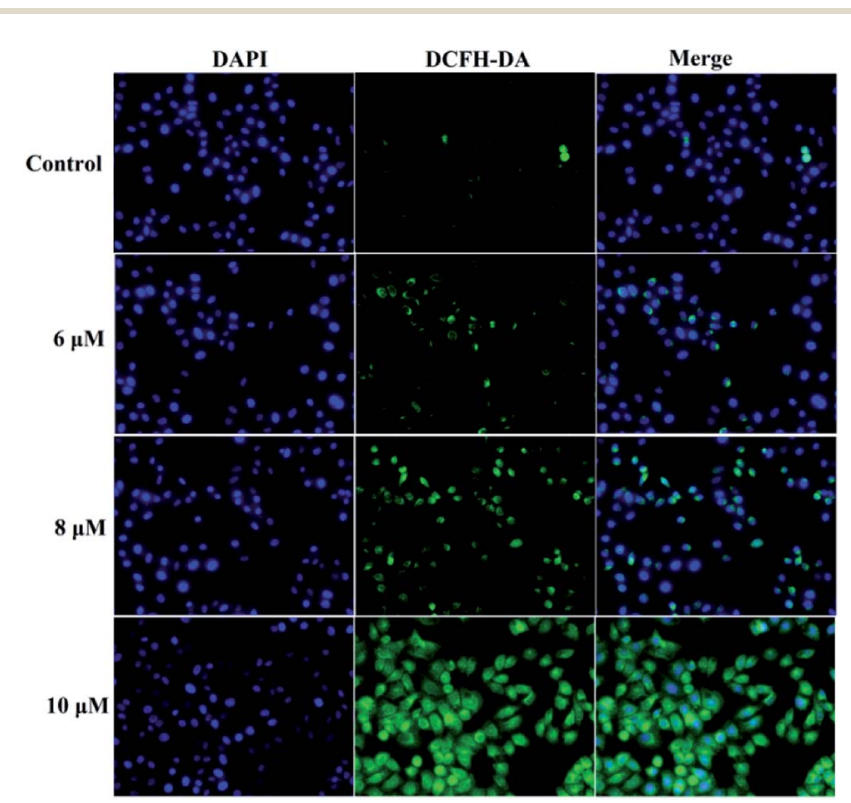

Fig. 8 Compound $3 a_{1}$ affected the levels of intracellular ROS in HepG2 cells. 


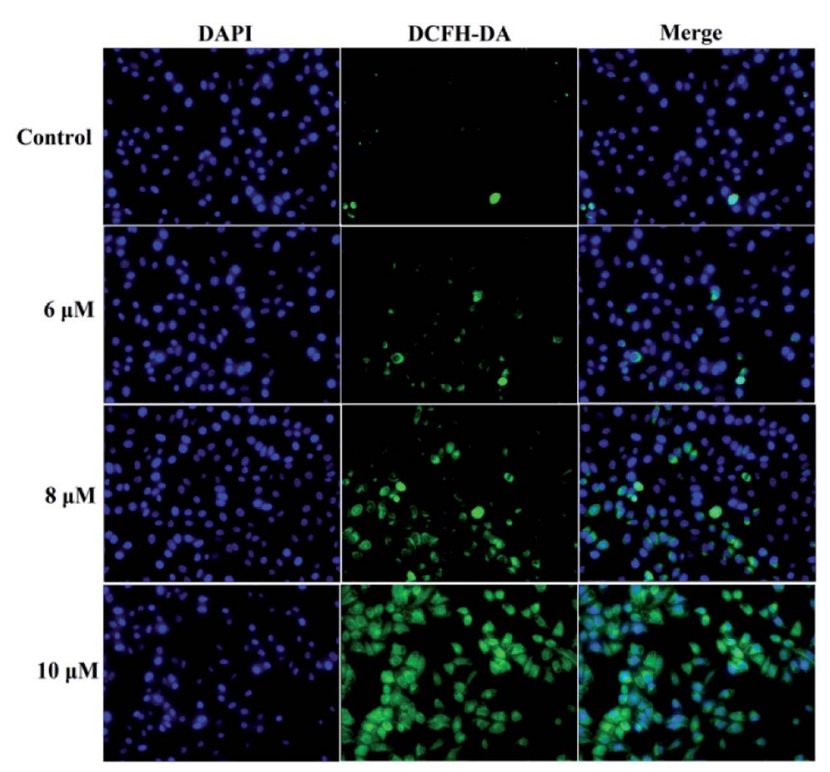

Fig. 9 Compound $3 a_{1}$ caused an increase in the level of intracellular $\mathrm{Ca}^{2+}$ in HepG2 cells.

apoptosis-inducing effect of compound $3 \mathbf{a}_{1}$ was investigated by staining with the fluorescent probes Hoechst 33258 and acridine orange/ethidium bromide (AO/EB). In the Hoechst 33258 staining assay (Fig. 5), normal HeGp2 cells emitted blue fluorescence, whereas the cells treated with $3 \mathrm{a}_{1}$ for $12 \mathrm{~h}$ exhibited stronger blue fluorescence and displayed characteristic apoptotic morphologies. This phenomenon indicated that compound $3 \mathbf{a}_{\mathbf{1}}$ induced the apoptosis of HeGp2 cells. ${ }^{21}$ In the $\mathrm{AO} / \mathrm{EB}$ staining assay, the morphology of $3 \mathbf{a}_{1}$-treated HeGp2 cells exhibited evident changes (Fig. 6). The cell nuclei were stained yellow/orange, and the morphology changes suggested pycnosis, membrane blebbing and cell budding, all of which are clear characteristics of apoptosis. ${ }^{21}$ Therefore, on the basis of the above-mentioned observations, it can be concluded that the compound $3 \mathbf{a}_{\mathbf{1}}$ induced apoptosis of HeGp2 cells.

The apoptosis ratios of HepG2 cells treated with $3 \mathbf{a}_{\mathbf{1}}$ were then quantitatively assayed by flow cytometry. As shown in
Fig. 7, the treatment of HepG2 cells with compound $3 \mathbf{a}_{\mathbf{1}}$ at different concentrations $(6,8$ and $10 \mu \mathrm{M})$ led to significant increase in the apoptotic cell population in a concentrationdependent manner. The results indicated that compound $\mathbf{3} \mathbf{a}_{\mathbf{1}}$ induced apoptosis of HepG2 cells in a dose-dependent manner.

\subsection{ROS generation}

A previous study proved that the generation of intracellular reactive oxygen species (ROS) can induce apoptosis. ${ }^{25}$ To investigate the role of ROS in $3 \mathbf{a}_{1}$-induced apoptosis in the HepG2 cells, intracellular ROS levels were determined through fluorescence microscopy using 4',6-diamidino-2-phenylindole dihydrochloride (DAPI) and 2,7-dichlorofluorescein diacetate (DCFH-DA) as fluorescent probes. Fig. 8 demonstrates that both control cells and HepG2 cells treated with compound $3 \mathbf{a}_{1}$ displayed blue fluorescence in the cytoplasm in the DAPI staining assay, whereas the HepG2 cells treated with compound $\mathbf{3} \mathbf{a}_{\mathbf{1}}$ exhibited stronger green fluorescence signals compared to the control in the DCFH-DA staining assay, indicating that $3 \mathbf{a}_{\mathbf{1}}$ can up-regulate the levels of intracellular ROS. These results indicated that the generation of ROS induced by $3 \mathbf{a}_{\mathbf{1}}$ may be an underlying cause for apoptosis. ${ }^{24}$

\subsection{Intracellular $\mathrm{Ca}^{2+}$ release}

It is known that intracellular calcium takes part in cell apoptosis, and an overload of calcium can induce apoptosis. ${ }^{26}$ Thus, the role of calcium signaling in cellular apoptosis induced by $\mathbf{3} \mathbf{a}_{\mathbf{1}}$ was studied. The HepG2 cells were treated with $3 \mathbf{a}_{1}$ for $24 \mathrm{~h}$, and the intracellular $\mathrm{Ca}^{2+}$ level was assayed by fluorescence microscopy using DCFH-DA as a calcium probe. Fig. 9 shows that the treatment of HepG2 cells with $3 \mathbf{a}_{1}$ caused an increase in the intracellular $\mathrm{Ca}^{2+}$ concentration, indicating that $3 \mathbf{a}_{\mathbf{1}}$-induced apoptosis was related to the up-regulation of intracellular $\mathrm{Ca}^{2+}$ level.

\subsection{Caspase-dependent apoptosis in HepG2 cells}

As well-known anti- and pro-apoptotic proteins, Bcl-2/Bax family proteins play important roles in the inhibition or
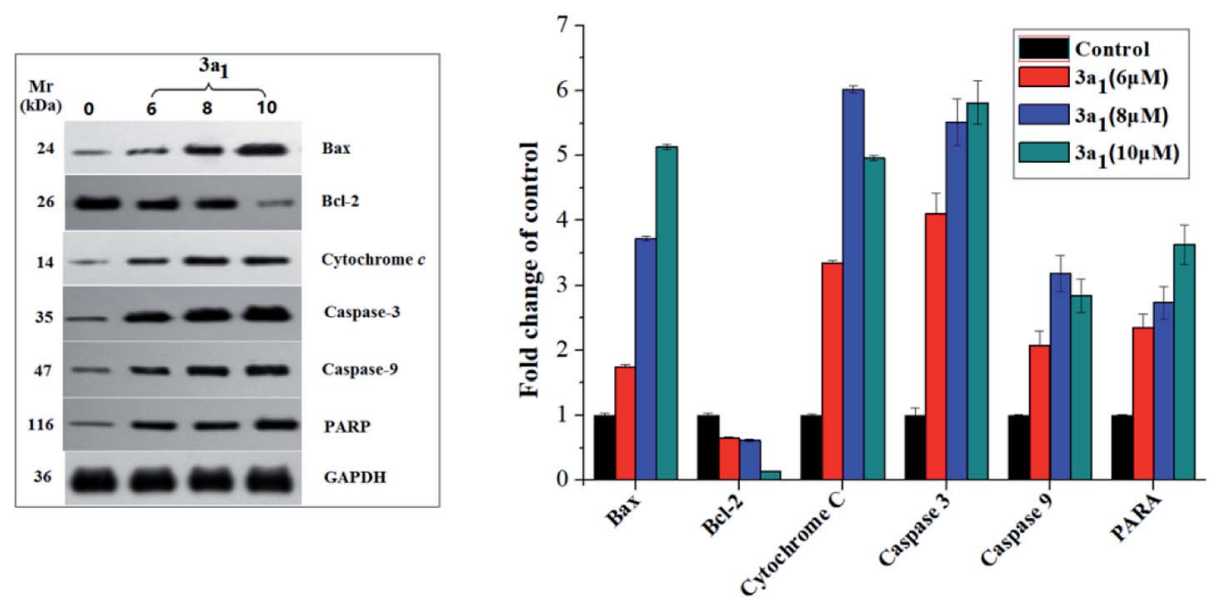

Fig. 10 Effect of compound $3 \mathrm{a}_{1}$ on the expression levels of Bax, $\mathrm{Bcl}-2$, cytochrome $\mathrm{c}$, caspase-3, caspase-9 and PARP in HepG2 cells. GAPDH was used as a loading standard. 
promotion of cell death. ${ }^{27,28}$ A previous study proved that the ratio of $\mathrm{Bcl}-2 / \mathrm{Bax}$ expression is vital in the regulation of apoptosis. ${ }^{29} \mathrm{Bcl}-2 / \mathrm{Bax}$ family proteins mainly participate in apoptosis by interfering with caspases, which are the pivotal effectors of programmed cell death. ${ }^{\mathbf{3 0 , 3 1}}$ Caspases are a family of cysteinyl aspartate specific proteases, which participate in apoptosis, and they can be divided into initiators (caspases 8, 9 and 10) and executioners (caspases 3, 6 and 7). ${ }^{30,31}$ The caspase cascade is mediated by the proteolysis of inactive procaspases and propagated by the cleavage of downstream caspases and substrates including poly(ADP-ribose) polymerase (PARP). ${ }^{21}$ To investigate the mechanism of $\mathbf{3} \mathbf{a}_{\mathbf{1}}$-induced apoptosis in cancer cells and to find if caspases were involved in $\mathbf{3} \mathbf{a}_{\mathbf{1}}$-induced apoptosis, the expression levels of Bax, Bcl-2, cytochrome $c$, caspase-9, caspase-3 and PARP in HepG2 cells treated with $\mathbf{3} \mathbf{a}_{\mathbf{1}}$ were assayed by western blot. As shown in Fig. 10, the treatment of HepG 2 cells with $\mathbf{3} \mathbf{a}_{\mathbf{1}}$ led to evident increase in the expression levels of Bax, caspase-9, caspase- 3 and PARP and reduction in the expression level of $\mathrm{Bcl}-2$ accompanied by the release of mitochondrial cytochrome $c$ into the cytosol compared to the observations for control. These results indicated that compound $3 \mathbf{a}_{1}$ could down-regulate the expression of $\mathrm{Bcl}-2$, leading to the release of cytochrome $c$, activation of caspase-9 and induction of apoptosis, thus demonstrating that compound $\mathbf{3} \mathbf{a}_{\mathbf{1}}$ exerted pro-apoptotic effects through a mitochondrial-mediated pathway and caspase cascade.

\section{Conclusions}

In summary, we designed and synthesized a set of 2-chloro-3(1H-benzo[ $d]$ imidazol-2-yl)quinoline derivatives and evaluated the antiproliferative activities of these compounds against four cancer cell lines (HepG2, SKOV-3, NCI-H460 and BEL-7404). We identified some compounds exhibiting high in vitro anticancer activities and low toxicities against normal HL-7702 cells. In vivo antitumor activity study and animal toxicology test showed that 3a $\mathbf{a}_{\mathbf{1}}$ exhibited potent antitumor activity in the HepG2 xenograft mouse model. Mechanistic studies showed that $\mathbf{3} \mathbf{a}_{\mathbf{1}}$ caused apoptosis of tumor cells possibly through regulation of the expression levels of apoptotic proteins (such as Bax, Bcl-2, cytochrome $c$, caspase-9, caspase-3, and PARP), intracellular $\mathrm{Ca}^{2+}$ release and ROS regulation. Cell cycle studies indicated that compound $\mathbf{3} \mathbf{a}_{\mathbf{1}}$ induced cell cycle arrest at the $\mathrm{G}_{2} / \mathbf{M}$ phase by inhibition of CDK activity and activation of the p53 protein. This study suggests that the rational design of 2-chloro-3- $(1 \mathrm{H}$ benzo[d]imidazol-2-yl)quinoline derivatives under the combination principle is a feasible method to discover new antitumor therapeutics.

\section{Experimental}

\subsection{Materials}

All chemicals of reagent grade were commercially available and used without further purification. NMR spectra were assayed on a BRUKER AVANCE AV 400/500 spectrometer using tetramethyl silane (TMS) as the internal standard. Mass spectra were obtained on a BRUKER ESQUIRE HCT spectrometer. The GelRed nucleic acid stain was purchased from Biotium.

\subsection{General synthesis procedure for compounds $3\left(3 a_{1}-3 d_{6}\right)$}

2-Chloro-quinoline-3-carbaldehyde derivatives $\mathbf{2}(\mathbf{2 a}-\mathbf{2 d})$ were synthesized by condensation of acetanilide derivatives $\mathbf{1}(\mathbf{1 a}-\mathbf{1 d})$ with DMF in the presence of phosphorus oxychloride, according to our previous study. ${ }^{15}$ 2-Chloro-quinoline 3-carbaldehyde derivatives $\mathbf{2}(\mathbf{2 a}-\mathbf{2 d})(\mathbf{m m o l}), o$-phenylenediamine derivatives $(1 \mathrm{mmol})$ and $3 \mathrm{~mL}$ methanol were mixed in a pressure tube and heated at $90{ }^{\circ} \mathrm{C}$ for $4 \mathrm{~h}$. After the reaction, the mixture was cooled to room temperature and filtered to obtain the product as yellow powder. If necessary, the target compounds $\mathbf{3}\left(\mathbf{3 a}_{\mathbf{1}}-\mathbf{3} \mathbf{d}_{\mathbf{6}}\right)$ were purified by column chromatography (silica 300-400 mesh) with acetic ether-petroleum benzine (v/v: 1/5) as an eluent.

3a. . Yield, 64.8\%; ${ }^{1} \mathrm{H}$ NMR (500 MHz, DMSO-d $\left.\mathrm{d}_{6}\right) 12.68(\mathrm{~s}$, 1H, NH), 8.97 (s, 1H, H-Ar), 8.20 (s, 1H, H-Ar), 8.06 (s, 1H, H-Ar), 7.92 (d, $J=8.4 \mathrm{~Hz}, 1 \mathrm{H}, \mathrm{H}-\mathrm{Ar}), 7.75$ (d, $J=8.1 \mathrm{~Hz}, 1 \mathrm{H}, \mathrm{H}-\mathrm{Ar}), 7.45$ (s, 2H, H-Ar), 2.36 (s, 6H, $\left.-\mathrm{CH}_{3}\right) ;{ }^{13} \mathrm{C}$ NMR (126 MHz, DMSO-d 6 ) $\delta$ 147.68, 147.21, 141.58, 132.36, 129.01, 128.44, 128.16, 126.87, 125.14, 20.50; ESI-HRMS, calculated $m / z$ for $\mathrm{C}_{18} \mathrm{H}_{14} \mathrm{ClN}_{3}[\mathrm{M}+$ $\mathrm{H}]^{+}$: 308.0955, found: 308.0972.

3a . Yield, 57.3\%; ${ }^{1} \mathrm{H}$ NMR (500 MHz, DMSO-d $\left.{ }_{6}\right) \delta 13.08(\mathrm{~s}$, $1 \mathrm{H}, \mathrm{NH}$ ), 9.01 (s, 1H, H-Ar), 8.20 (d, $J=7.6 \mathrm{~Hz}, 1 \mathrm{H}, \mathrm{H}-\mathrm{Ar}$ ), 8.07 (d, $J=8.5 \mathrm{~Hz}, 1 \mathrm{H}, \mathrm{H}-\mathrm{Ar}), 7.95$ (d, $J=8.4 \mathrm{~Hz}, 1 \mathrm{H}, \mathrm{H}-\mathrm{Ar}), 7.77(\mathrm{~s}, 1 \mathrm{H}$, H-Ar), 7.70 (s, 1H, H-Ar), 7.50 (s, 1H, H-Ar), 7.16 (d, $J=8.5 \mathrm{~Hz}$, $1 \mathrm{H}, \mathrm{H}-\mathrm{Ar}) ;{ }^{13} \mathrm{C}$ NMR (126 MHz, DMSO-d 6 ) $\delta$ 147.48, 147.36, $141.99,132.66,129.11,128.58,128.19$, 126.79, 124.57; ESIHRMS, calculated $m / z$ for $\mathrm{C}_{16} \mathrm{H}_{9} \mathrm{ClFN}_{3}[\mathrm{M}+\mathrm{H}]^{+}:$298.0547, found: 298.0543 .

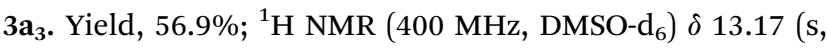
1H, NH), 9.03 (s, 1H, H-Ar), 8.21 (d, J=8.0 Hz, 1H, H-Ar), 8.08 (d, $J=8.4 \mathrm{~Hz}, 1 \mathrm{H}, \mathrm{H}-\mathrm{Ar}$ ), 7.95 (s, 1H, H-Ar), 7.77 (s, 2H, H-Ar), 7.70 (s, 1H, H-Ar), 7.32 (s, 1H, H-Ar); ${ }^{13} \mathrm{C}$ NMR (101 MHz, DMSO-d 6 ) $\delta$ 147.43, 147.40, 142.16, 132.75, 129.15, 128.61, 128.20, 126.77, 124.41; ESI-HRMS, calculated $m / z$ for $\mathrm{C}_{16} \mathrm{H}_{9} \mathrm{Cl}_{2} \mathrm{~N}_{3}[\mathrm{M}-\mathrm{H}]^{-}$: 312.0096, found: 312.0098.

3a . Yield, 55.4\%; ${ }^{1} \mathrm{H}$ NMR (500 MHz, DMSO-d $\left.\mathrm{d}_{6}\right) \delta 13.18(\mathrm{~s}$, 1H, NH), 9.02 (s, 1H, H-Ar), 8.21 (d, J= 7.7 Hz, 1H, H-Ar), 8.07 (d, $J=7.9 \mathrm{~Hz}, 1 \mathrm{H}, \mathrm{H}-\mathrm{Ar}$ ), 7.95 (s, 1H, H-Ar), 7.91 (s, 1H, H-Ar), 7.77 (s, 1H, H-Ar), 7.67 (s, 1H, H-Ar), 7.44 (s, 1H, H-Ar); ${ }^{13} \mathrm{C}$ NMR (126 MHz, DMSO-d $\left.\mathrm{d}_{6}\right) \delta 147.44,147.42,142.14,132.75,129.14,128.61$, 128.20, 126.76, 124.38; ESI-HRMS, calculated $\mathrm{m} / z$ for $\mathrm{C}_{16} \mathrm{H}_{9^{-}}$ $\mathrm{BrClN}_{3}[\mathrm{M}-\mathrm{H}]^{-}:$355.9590, found: 355.9625.

3a . Yield, 55.1\%; ${ }^{1} \mathrm{H}$ NMR (400 MHz, DMSO-d $\left.{ }_{6}\right) \delta 13.30(\mathrm{~s}$, 1H, NH), 9.03 (s, 1H, H-Ar), 8.21 (d, $J=7.6 \mathrm{~Hz}, 1 \mathrm{H}, \mathrm{H}-\mathrm{Ar}$ ), 8.08 (d, $J=8.4 \mathrm{~Hz}, 2 \mathrm{H}, \mathrm{H}-\mathrm{Ar}$ ), 7.96 (s, 2H, H-Ar), 7.77 (s, 1H, H-Ar); ${ }^{13} \mathrm{C}$ NMR (101 MHz, DMSO-d 6 ) $\delta$ 150.82, 147.47, 147.32, 142.32, 132.89, 129.19, 128.67, 128.21, 126.71, 124.03; ESI-HRMS, calculated $\mathrm{m} / \mathrm{z}$ for $\mathrm{C}_{16} \mathrm{H}_{8} \mathrm{Cl}_{3} \mathrm{~N}_{3}[\mathrm{M}-\mathrm{H}]^{-}$: 345.9706, found: 345.9747.

3a . Yield, 63.2\%; ${ }^{1} \mathrm{H}$ NMR (400 MHz, DMSO-d $\left.{ }_{6}\right) \delta 12.97(\mathrm{~s}$, $1 \mathrm{H}, \mathrm{NH}$ ), 9.01 (s, 1H, H-Ar), 8.21 (d, J= 7.4 Hz, 1H, H-Ar), 8.08 (d, $J=8.0 \mathrm{~Hz}, 1 \mathrm{H}, \mathrm{H}-\mathrm{Ar}$ ), 7.94 (s, 1H, H-Ar), 7.77 (s, 2H, H-Ar), 7.67 (s, 1H, H-Ar), 7.30 (s, 2H, H-Ar); ${ }^{13} \mathrm{C}$ NMR (101 MHz, DMSO-d ${ }_{6}$ ) 
$\delta$ 148.21, 147.63, 147.31, 141.97, 132.58, 129.09, 128.55, 128.19, 126.83, 124.92; ESI-HRMS, calculated $m / z$ for $\mathrm{C}_{16} \mathrm{H}_{10} \mathrm{ClN}_{3}[\mathrm{M}-$ $\mathrm{H}]^{-}$: 278.0485, found: 278.0489 .

$3 \mathbf{b}_{1}$. Yield, 58.1\%; ${ }^{1} \mathrm{H}$ NMR (500 MHz, DMSO-d $\left.{ }_{6}\right) \delta 12.66(\mathrm{~s}$, 1H, NH), 8.84 (s, 1H, H-Ar), 7.94 (s, 2H, H-Ar), 7.84 (s, 1H, H-Ar), 7.46 (s, 2H, H-Ar), 2.54 (s, 3H, $\left.-\mathrm{CH}_{3}\right), 2.36\left(\mathrm{~s}, 6 \mathrm{H},-\mathrm{CH}_{3}\right) ;{ }^{13} \mathrm{C}$ NMR (126 MHz, DMSO-d 6 ) $\delta$ 147.32, 146.78, 145.84, 140.84, 138.21, 134.49, 127.90, 127.54, 126.88, 125.09, 21.62, 20.50; ESIHRMS, calculated $m / z$ for $\mathrm{C}_{19} \mathrm{H}_{16} \mathrm{ClN}_{3}[\mathrm{M}+\mathrm{H}]^{+}: 322.1111$, found: 322.1129.

$3 \mathbf{b}_{2}$. Yield, 64.6\%; ${ }^{1} \mathrm{H}$ NMR (400 MHz, DMSO-d $\left.{ }_{6}\right) \delta 12.14(\mathrm{~s}$, $1 \mathrm{H}, \mathrm{NH}), 8.87$ (s, 1H, H-Ar), 7.96 (d, J=8.6 Hz, 1H, H-Ar), 7.94 (s, 1H, H-Ar), 7.77 (d, J=8.6 Hz, 1H, H-Ar), 7.70 (s, 1H, H-Ar), 7.51 (s, 1H, H-Ar), 7.16 (s, 1H, H-Ar), 2.54 (s, 3H, $\left.-\mathrm{CH}_{3}\right) ;{ }^{13} \mathrm{C}$ NMR (101 MHz, DMSO-d $\left.{ }_{6}\right) \delta 146.57,145.98,141.23,138.35,134.76,127.92$, 127.61, 126.79, 124.52, 21.62; ESI-HRMS, calculated $\mathrm{m} / \mathrm{z}$ for $\mathrm{C}_{17} \mathrm{H}_{11} \mathrm{ClFN}_{3}[\mathrm{M}+\mathrm{H}]^{+}:$312.0704, found: 312.0702.

3b $\mathbf{b}_{3}$. Yield, 55.9\%; ${ }^{1} \mathrm{H}$ NMR (400 MHz, DMSO-d $\left.{ }_{6}\right) \delta 13.13(\mathrm{~s}$, $1 \mathrm{H}, \mathrm{NH}$ ), 8.88 (s, 1H, H-Ar), 7.97 (d, J=8.7 Hz, 1H, H-Ar), 7.95 (s, $1 \mathrm{H}, \mathrm{H}-\mathrm{Ar}$ ), 7.78 (d, $J=8.6 \mathrm{~Hz}, 2 \mathrm{H}, \mathrm{H}-\mathrm{Ar}$ ), 7.70 (s, 1H, H-Ar), 7.32 $(\mathrm{d}, J=8.6 \mathrm{~Hz}, 1 \mathrm{H}, \mathrm{H}-\mathrm{Ar}), 2.54\left(\mathrm{~s}, 3 \mathrm{H},-\mathrm{CH}_{3}\right) ;{ }^{13} \mathrm{C} \mathrm{NMR}(101 \mathrm{MHz}$, DMSO-d $\left._{6}\right) \delta 146.53,146.04,141.38,138.40,134.86,127.94$, 127.64, 126.77, 124.36, 21.64; ESI-HRMS, calculated $\mathrm{m} / \mathrm{z}$ for $\mathrm{C}_{17} \mathrm{H}_{11} \mathrm{Cl}_{2} \mathrm{~N}_{3}[\mathrm{M}-\mathrm{H}]^{-}$: 326.0252, found: 326.0255 .

3b $\mathbf{b}_{4}$. Yield, 61.0\%; ${ }^{1} \mathrm{H}$ NMR (400 MHz, DMSO-d $\left.{ }_{6}\right) \delta 13.16(\mathrm{~s}$, $1 \mathrm{H}, \mathrm{NH}$ ), 8.88 (s, 1H, H-Ar), 7.97 (d, J=8.8 Hz, 1H, H-Ar), 7.95 (s, 1H, H-Ar), 7.78 (d, $J=8.6 \mathrm{~Hz}, 1 \mathrm{H}, \mathrm{H}-\mathrm{Ar}$ ), 7.73 (s, 1H, H-Ar), 7.68 (s, 1H, H-Ar), 7.43 (d, J=8.3 Hz, 1H, H-Ar), $2.54\left(\mathrm{~s}, 3 \mathrm{H},-\mathrm{CH}_{3}\right)$; ${ }^{13} \mathrm{C}$ NMR (101 MHz, DMSO-d ${ }_{6}$ ) $\delta 146.53,146.04,141.40,138.41$, 134.87, 127.94, 127.65, 126.77, 124.34, 21.64; ESI-HRMS, calculated $m / z$ for $\mathrm{C}_{17} \mathrm{H}_{11} \mathrm{BrClN}_{3}[\mathrm{M}-\mathrm{H}]^{-}$: 369.9747 , found: 369.9774 .

$3^{3} \mathbf{b}_{5}$. Yield, 59.9\%; ${ }^{1} \mathrm{H}$ NMR (500 MHz, DMSO-d $\left.{ }_{6}\right) \delta 13.26(\mathrm{~s}$, $1 \mathrm{H}, \mathrm{NH}), 8.88$ (s, 1H, H-Ar), 7.96 (d, J=8.6 Hz, 2H, H-Ar), 7.94 (s, 2H, H-Ar), 7.78 (s, 1H, H-Ar), 2.54 (s, 3H, $\left.-\mathrm{CH}_{3}\right) ;{ }^{13} \mathrm{C}$ NMR (126 MHz, DMSO-d $\left.{ }_{6}\right) \delta 150.92,146.41,146.14,141.46,138.44,134.94$, 127.94, 127.66, 126.71, 123.99, 21.61; ESI-HRMS, calculated $\mathrm{m} / \mathrm{z}$ for $\mathrm{C}_{17} \mathrm{H}_{11} \mathrm{BrClN}_{3}[\mathrm{M}-\mathrm{H}]^{-}$: 359.9862, found: 359.9903 .

3b $\mathbf{b}_{6}$. Yield, 61.7\%; ${ }^{1} \mathrm{H}$ NMR (400 MHz, DMSO-d $\left.{ }_{6}\right) \delta 12.96(\mathrm{~s}$, 1H, NH), 8.87 (s, 1H, H-Ar), 7.97 (d, J=8.7 Hz, 1H, H-Ar), 7.95 (s, 1H, H-Ar), 7.77 (d, $J=8.6 \mathrm{~Hz}, 1 \mathrm{H}, \mathrm{H}-\mathrm{Ar}$ ), 7.69 (s, 2H, H-Ar), 7.29 (d, $J=6.0 \mathrm{~Hz}, 2 \mathrm{H}, \mathrm{H}-\mathrm{Ar}), 2.54\left(\mathrm{~s}, 3 \mathrm{H},-\mathrm{CH}_{3}\right) ;{ }^{13} \mathrm{C}$ NMR $(101 \mathrm{MHz}$, DMSO-d $\left._{6}\right) \delta 148.32,146.73,145.95,141.19,138.32,134.69$, 127.93, 127.60, 126.83, 124.87, 21.64; ESI-HRMS, calculated $\mathrm{m} / \mathrm{z}$ for $\mathrm{C}_{17} \mathrm{H}_{12} \mathrm{ClN}_{3}[\mathrm{M}+\mathrm{H}]^{+}$: 294.0798, found: 294.0790.

$3 \mathbf{c}_{1}$. Yield, 59.0\%; ${ }^{1} \mathrm{H}$ NMR (500 MHz, DMSO-d $\left.{ }_{6}\right) \delta 12.78(\mathrm{~s}$, $1 \mathrm{H}, \mathrm{NH}), 8.84$ (s, 1H, H-Ar), 7.96 (d, J=9.2 Hz, 1H, H-Ar), 7.60 (s, 1H, H-Ar), 7.55 (d, J=9.1 Hz, 1H, H-Ar), 7.46 (s, 2H, H-Ar), 3.93 $\left(\mathrm{s}, 3 \mathrm{H},-\mathrm{OCH}_{3}\right), 2.36\left(\mathrm{~s}, 6 \mathrm{H},-\mathrm{CH}_{3}\right) ;{ }^{13} \mathrm{C}$ NMR $(126 \mathrm{MHz}, \mathrm{DMSO}-$ $\left.\mathrm{d}_{6}\right) \delta 158.70,147.27,144.89,143.27,140.29,131.65,129.64$, 128.16, 125.06, 124.67, 106.81, 56.24, 20.49; ESI-HRMS, calculated $m / z$ for $\mathrm{C}_{19} \mathrm{H}_{16} \mathrm{ClN}_{3} \mathrm{O}[\mathrm{M}+\mathrm{H}]^{+}$: 338.1060, found: 338.1076.

$3 \mathbf{c}_{2}$. Yield, 56.4\%; ${ }^{1} \mathrm{H}$ NMR (500 MHz, DMSO-d $\left.{ }_{6}\right) \delta 13.05(\mathrm{~s}$, $1 \mathrm{H}, \mathrm{NH}), 8.87$ (s, 1H, H-Ar), 7.97 (d, J=9.1 Hz, 1H, H-Ar), 7.76 (s, 1H, H-Ar), 7.59 (s, 1H, H-Ar), 7.57 (d, J=9.1 Hz, 1H, H-Ar), 7.44 (s, 1H, H-Ar), 7.15 (s, 1H, H-Ar), 3.93 (s, 3H, $-\mathrm{OCH}_{3}$ ); ${ }^{13} \mathrm{C}$ NMR (126 MHz, DMSO-d 6 ) $\delta 158.70,143.38,129.65,128.11,124.92$,
124.66, 106.76, 56.23; ESI-HRMS, calculated $\mathrm{m} / \mathrm{z}$ for $\mathrm{C}_{17} \mathrm{H}_{11^{-}}$ $\mathrm{ClFN}_{3} \mathrm{O}[\mathrm{M}+\mathrm{H}]^{+}:$328.0653, found: 328.0640 .

$3 \mathbf{c}_{3}$. Yield 55.1\%, ${ }^{1} \mathrm{H}$ NMR (400 MHz, DMSO-d $\left.{ }_{6}\right) \delta 13.12(\mathrm{~s}$, $1 \mathrm{H}, \mathrm{NH}), 8.88$ (s, 1H, H-Ar), 7.98 (d, J=9.0 Hz, 1H, H-Ar), 7.76 (s, 1H, H-Ar), 7.70 (s, 1H, H-Ar), 7.60 (s, 1H, H-Ar), 7.58 (d, $J=$ $9.0 \mathrm{~Hz}, 1 \mathrm{H}, \mathrm{H}-\mathrm{Ar}$ ), 7.32 (d, $J=8.6 \mathrm{~Hz}, 1 \mathrm{H}, \mathrm{H}-\mathrm{Ar}), 3.93(\mathrm{~s}, 3 \mathrm{H}$, $\left.-\mathrm{OCH}_{3}\right) ;{ }^{13} \mathrm{C}$ NMR $\left(101 \mathrm{MHz}, \mathrm{DMSO}-\mathrm{d}_{6}\right) \delta 158.74,149.73,144.65$, 143.45, 140.73, 129.68, 128.10, 125.02, 124.51, 106.81, 56.26; ESI-HRMS $\mathrm{m} / \mathrm{z}$ calc. for $\mathrm{C}_{17} \mathrm{H}_{11} \mathrm{Cl}_{2} \mathrm{~N}_{3} \mathrm{O}[\mathrm{M}-\mathrm{H}]^{-}$: 342.0201; found: 342.0205 .

3c $\mathbf{c}_{4}$. Yield, 57.1\%; ${ }^{1} \mathrm{H}$ NMR (400 MHz, DMSO-d $\left.{ }_{6}\right) \delta 13.14(\mathrm{~s}$, $1 \mathrm{H}, \mathrm{NH}), 8.88$ (s, 1H, H-Ar), 7.98 (d, J=9.1 Hz, 1H, H-Ar), 7.90 (s, 1H, H-Ar), 7.68 (s, 1H, H-Ar), 7.60 (s, 1H, H-Ar), 7.58 (d, $J=$ $9.1 \mathrm{~Hz}, 1 \mathrm{H}, \mathrm{H}-\mathrm{Ar}), 7.43$ (d, $J=8.4 \mathrm{~Hz}, 1 \mathrm{H}, \mathrm{H}-\mathrm{Ar}), 3.93(\mathrm{~s}, 3 \mathrm{H}$, $\left.-\mathrm{OCH}_{3}\right) ;{ }^{13} \mathrm{C}$ NMR $\left(101 \mathrm{MHz}, \mathrm{DMSO}-\mathrm{d}_{6}\right) \delta 158.73,144.64,143.45$, 140.75, 129.68, 128.10, 125.04, 124.47, 106.80, 56.26; ESI-HRMS, calculated $m / z$ for $\mathrm{C}_{17} \mathrm{H}_{11} \mathrm{Cl}_{2} \mathrm{~N}_{3} \mathrm{O}[\mathrm{M}-\mathrm{H}]^{-}$: 385.9696, found: 385.9715 .

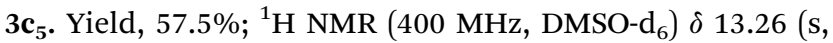
1H, NH), 8.88 (s, 1H, H-Ar), 7.97 (s, 3H, H-Ar), 7.60 (s, 2H, H-Ar), 3.93 (s, 3H, $-\mathrm{OCH}_{3}$ ); ${ }^{13} \mathrm{C}$ NMR (101 MHz, DMSO-d $\left.\mathrm{d}_{6}\right) \delta 158.77$, 150.93, 144.53, 143.52, 140.87, 129.69, 128.05, 125.15, 124.12, $106.85,56.27$; ESI-HRMS, calculated $m / z$ for $\mathrm{C}_{17} \mathrm{H}_{11} \mathrm{Cl}_{2} \mathrm{~N}_{3} \mathrm{O}[\mathrm{M}-$ $\mathrm{H}]^{-}$: 375.9811 , found: 378.9859 .

3c 6 . Yield, 65.1\%; ${ }^{1} \mathrm{H}$ NMR (400 MHz, DMSO-d $\left.{ }_{6}\right) \delta 12.68(\mathrm{~s}$, 1H, NH), 9.10 (s, 1H, H-Ar), 7.75 (s, 1H, H-Ar), 7.66 (s, 1H, H-Ar), 7.52 (s, 1H, H-Ar), 7.39 (d, J = 9.0 Hz, 1H, H-Ar), 7.29 (s, 1H, HAr), 7.22 (s, 1H, H-Ar), 7.20 (s, 1H, H-Ar), $3.84\left(\mathrm{~s}, 3 \mathrm{H},-\mathrm{OCH}_{3}\right) ;{ }^{13} \mathrm{C}$ NMR (101 MHz, DMSO-d 6 ) $\delta$ 160.79, 155.14, 148.34, 143.27, 139.05, 134.88, 133.84, 122.73, 122.36, 121.76, 120.64, 120.25, 118.77, 117.06, 113.27, 110.27, 56.00; ESI-HRMS, calculated $\mathrm{m} / \mathrm{z}$ for $\mathrm{C}_{17} \mathrm{H}_{12} \mathrm{ClN}_{3} \mathrm{O}[\mathrm{M}+\mathrm{H}]^{+}$: 310.0747, found: 310.0741 .

3d . Yield, 64.5\%; ${ }^{1} \mathrm{H}$ NMR (400 MHz, DMSO-d ${ }_{6}$ ) $\delta 12.59(\mathrm{~s}$, 1H, NH), 8.75 (s, 1H, H-Ar), 7.54 (s, 1H, H-Ar), 7.42 (s, 3H, H-Ar), $6.29\left(\mathrm{~s}, 2 \mathrm{H}, \mathrm{O}-\mathrm{CH}_{2}-\mathrm{O}\right), 2.34\left(\mathrm{~s}, 6 \mathrm{H},-\mathrm{CH}_{3}\right) ;{ }^{13} \mathrm{C}$ NMR $(101 \mathrm{MHz}$, DMSO-d $\left._{6}\right) \delta 152.93,149.06,147.43,145.92,145.06,140.02$, 124.16, 122.81, 104.52, 103.46, 103.22, 20.54; ESI-HRMS, calculated $m / z$ for $\mathrm{C}_{19} \mathrm{H}_{14} \mathrm{ClN}_{3} \mathrm{O}_{2}[\mathrm{M}+\mathrm{H}]^{+}: 352.0853$, found: 352.0880 .

3d $\mathbf{d}_{2}$. Yield, 58.9\%; ${ }^{1} \mathrm{H}$ NMR (500 MHz, DMSO-d $\left.{ }_{6}\right) \delta 12.96(\mathrm{~s}$, 1H, NH), 8.77 (s, 1H, H-Ar), 7.68 (s, 1H, H-Ar), 7.54 (s, 1H, H-Ar), 7.47 (s, 1H, H-Ar), 7.43 (s, 1H, H-Ar), 7.14 (s, 1H, H-Ar), 6.30 (s, $\left.2 \mathrm{H}, \mathrm{O}-\mathrm{CH}_{2}-\mathrm{O}\right) ;{ }^{13} \mathrm{C}$ NMR $\left(126 \mathrm{MHz}, \mathrm{DMSO}_{6}\right) \delta$ 153.14, 149.15, $146.17,144.91,140.25$, 124.12, 122.24, 104.55, 103.52, 103.28, 100.00; ESI-HRMS, calculated $m / z$ for $\mathrm{C}_{17} \mathrm{H}_{9} \mathrm{ClFN}_{3} \mathrm{O}_{2}[\mathrm{M}+\mathrm{H}]^{+}$: 342.0446, found: 342.0429 .

3d . Yield, 59.1\%; ${ }^{1} \mathrm{H}$ NMR (400 MHz, DMSO-d $\left.{ }_{6}\right) \delta 13.05(\mathrm{~s}$, 1H, NH), 8.79 (s, 1H, H-Ar), 7.78 (s, 1H, H-Ar), 7.65 (s, 1H, H-Ar), 7.56 (s, 1H, H-Ar), 7.44 (s, 1H, H-Ar), 7.30 (d, J=8.1 Hz, 1H, HAr), 6.30 (s, 2H, O-CH $\left.{ }_{2}-\mathrm{O}\right) ;{ }^{13} \mathrm{C}$ NMR (101 MHz, DMSO-d ${ }_{6}$ ) $\delta$ 153.22, 149.19, 146.25, 144.87, 140.40, 124.12, 122.08, 104.57, 103.54, 103.32; ESI-HRMS, calculated $m / z$ for $\mathrm{C}_{17} \mathrm{H}_{9} \mathrm{Cl}_{2} \mathrm{~N}_{3} \mathrm{O}_{2}[\mathrm{M}$ $-\mathrm{H}]^{-}$: 355.9994, found: 355.9999 .

3d $\mathbf{d}_{4}$. Yield, 68.6\%; ${ }^{1} \mathrm{H}$ NMR (400 MHz, DMSO-d $\left.{ }_{6}\right) \delta 13.04(\mathrm{~s}$, 1H, NH), 8.79 (s, 1H, H-Ar), 7.87 (s, 1H, H-Ar), 7.64 (s, 1H, H-Ar), 7.55 (s, 1H, H-Ar), 7.44 (s, 1H, H-Ar), 7.41 (d, J=8.6 Hz, 1H, HAr), 6.30 (s, 2H, O- $\left.\mathrm{CH}_{2}-\mathrm{O}\right) ;{ }^{13} \mathrm{C}$ NMR (101 MHz, DMSO-d $\left.{ }_{6}\right)$ 
$\delta$ 153.22, 149.18, 146.25, 144.86, 140.40, 124.11, 122.04, 104.57, 103.54, 103.31; ESI-HRMS, calculated $m / z$ for $\mathrm{C}_{17} \mathrm{H}_{9} \mathrm{BrClN}_{3} \mathrm{O}_{2}[\mathrm{M}$ $-\mathrm{H}]^{-}: 399.9489$, found: 399.9508 .

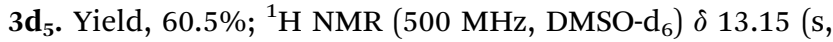
1H, NH), 8.79 (s, 1H, H-Ar), 7.96 (s, 2H, H-Ar), 7.56 (s, 1H, H-Ar), 7.44 (s, 1H, H-Ar), 6.30 (s, 2H, O- $\left.\mathrm{CH}_{2}-\mathrm{O}\right) ;{ }^{13} \mathrm{C}$ NMR $(126 \mathrm{MHz}$, DMSO-d $\left._{6}\right) \delta 153.32,151.05,149.23,146.38,144.79,140.46$, 131.96, 129.12, 124.07, 121.69, 104.58, 103.57, 103.33; ESIHRMS, calculated $m / z$ for $\mathrm{C}_{17} \mathrm{H}_{8} \mathrm{Cl}_{3} \mathrm{~N}_{3} \mathrm{O}_{2}[\mathrm{M}-\mathrm{H}]^{-}:$389.9604, found: 389.9649 .

3d . Yield, 62.2\%; ${ }^{1} \mathrm{H}$ NMR (400 MHz, DMSO-d $\left.{ }_{6}\right) \delta 12.96(\mathrm{~s}$, $1 \mathrm{H}, \mathrm{NH}$ ), 8.78 (s, 1H, H-Ar), 7.67 (s, 2H, H-Ar), 7.55 (s, 1H, H-Ar), 7.44 (s, 1H, H-Ar), 7.27 (s, 2H, H-Ar), 6.30 (s, 2H, O- $\left.\mathrm{CH}_{2}-\mathrm{O}\right) ;{ }^{13} \mathrm{C}$ NMR (101 MHz, DMSO-d 6 ) $\delta$ 153.07, 149.12, 148.42, 146.10, 145.04, 140.27, 124.14, 122.89, 122.55, 104.55, 103.50, 103.27; ESI-HRMS, calculated $m / z$ for $\mathrm{C}_{17} \mathrm{H}_{10} \mathrm{ClN}_{3} \mathrm{O}_{2}[\mathrm{M}+\mathrm{H}]^{+}$: 324.0540, found: 324.0532 .

\subsection{Biological assays}

The procedures for biological assays are described in the ESI $\dagger$ (Part 1). The materials, instrumentation, and methods for the cytotoxicity assay, cell cycle analysis, cell apoptosis analysis and western blot assays were reported previously. ${ }^{17,32-34}$

\section{Ethical statement}

The in vivo antitumor studies were carried out at the Institute of Radiation Medicine, Chinese Academy of Medical Sciences (Tian Jin, China). The handling of animals and experimental design were approved by the Ethics Committee and Animal Care Committee of the Institute.

\section{Conflicts of interest}

The authors declare no competing financial interest.

\section{Abbreviations used}

$\begin{array}{ll}\text { Bax } & \text { Bcl2-associated X protein } \\ \text { PI } & \text { Propidium iodide } \\ \text { EB } & \text { Ethidium bromide } \\ \text { MTT } & \text { 3-(4,5-Dimethylthiazol-2-yl)-2,5-diphenyltetrazolium } \\ & \text { bromide } \\ \text { CDC } & \text { Cell division cyclin } \\ \text { CDK } & \text { Cyclin-dependent kinase } \\ \text { CDC25C } & \text { Cell division cyclin 25 homolog C }\end{array}$

\section{Acknowledgements}

This study was supported by the National Natural Science Foundation of China (No. 21501032), the Innovative Team \& Outstanding Talent Program of Colleges and Universities in Guangxi (2017-38), Guangxi Natural Science Foundation (Nos. 2016GXNSFAA380300 and 2014GXNSFBA118050), Guangxi New Century Ten, Hundred and Thousand Talents Project ([2017]42) and the State Key Laboratory Cultivation Base for Chemistry and Molecular Engineering of Medicinal Resources (Ministry of Science and Technology of China, No. CMEMR2014-B14).

\section{Notes and references}

1 World Cancer Report (World Health Organization, International Agency for Cancer Research), ed. B. Stewart and P. Kleihues, IARC Press, Lyon, 2003.

2 D. M. Parkin, Global cancer statistics in the year 2000, Lancet Oncol., 2001, 2, 533-543.

3 A. Anighoro, J. Bajorath and G. Rastelli, Polypharmacology: challenges and opportunities in drug discovery, J. Med. Chem., 2014, 57, 7874-7887.

$4 \mathrm{~S}$. Fortin and G. Berube, Advances in the development of hybrid anticancer drugs, Expert Opin. Drug Discovery, 2013, 8, 1029-1047.

5 S. Kumar, S. Bawa and H. Gupta, Biological activities of quinoline derivatives, Mini-Rev. Med. Chem., 2009, 9, 16481654.

6 C. H. Tseng, C. C. Tzeng, C. L. Yang, P. J. Lu, H. L. Chen, H. Y. Li, et al., Synthesis and antiproliferative evaluation of certain indeno[1,2-c] quinoline derivatives. Part 2, J. Med. Chem., 2010, 53, 6164-6179.

7 C. H. Tseng, Y. L. Chen, P. J. Lu, C. N. Yang and C. C. Tzeng, Synthesis and antiproliferative evaluation of certain indeno [1,2-c]quinoline derivatives, Bioorg. Med. Chem., 2008, 16, 3153-3162.

8 P. M. Njaria, J. Okombo, N. M. Njuguna and K. Chibale, Chloroquine-containing compounds: a patent review (2010-2014), Expert Opin. Ther. Pat., 2015, 25, 1003-1024.

9 T. Kimura, Y. Takabatake, A. Takahashi and Y. Isaka, Chloroquine in cancer therapy: a double-edged sword of autophagy, Cancer Res., 2013, 73, 3-7.

10 L. L. Brunton, J. S. Lazo and K. L. Parker, The pharmacological basis of therapeutics, Mc Graw-Hill, New York, 11th edn, 2006.

11 V. Králová, V. Hanušová, E. Rudolf, K. Čáňová and L. Skálová, Flubendazole induces mitotic catastrophe and senescence in colon cancer cells in vitro, J. Pharm. Pharmacol., 2016, 68, 208-218.

12 N. S. El-Gohary and M. I. Shaaban, Synthesis, antimicrobial, antiquorum-sensing and antitumor activities of new benzimidazole analogs, Eur. J. Med. Chem., 2017, 137, 439449.

13 F. Gümüş, G. Eren, L. Açık, A. Çelebi, F. Öztürk, Ş. Yılmaz, R. I. Sağkan, S. Gür, A. Özkul, A. Elmal and Y. Elerman, Synthesis, Cytotoxicity, and DNA Interactions of New Cisplatin Analogues Containing Substituted Benzimidazole Ligands, J. Med. Chem., 2009, 52, 1345-1357.

14 C.-C. Chiu, H.-L. Chou, B.-H. Chen, K.-F. Chang, C.-H. Tseng, Y. Fong, T.-F. Fu, H.-W. Chang, C.-Y. Wu, E.-M. Tsai, S.-R. Lin and Y.-L. Chen, BPIQ, a novel synthetic quinoline derivative, inhibits growth and induces mitochondrial apoptosis of lung cancer cells in vitro and in zebrafish xenograft model, BMC Cancer, 2015, 15, 962. 
15 Y. C. Yu, W. B. Kuang, R. Z. Huang, Y. L. Fang, Y. Zhang, Z. F. Chen and X. L. Ma, Design, synthesis and pharmacological evaluation of new 2-oxoquinoline derivatives containing $\alpha$-aminophosphonates as potential antitumor agents, MedChemComm, 2017, 8, 1158-1172.

16 V. Lakshma Nayak, N. Nagesh, A. Ravikumar, C. Bagul, M. V. P. S. Vishnuvardhan, V. Srinivasulu and A. Kamal, 2aryl benzimidazole conjugate induced apoptosis in human breast cancer MCF-7 cells through caspase independent pathway, Apoptosis, 2017, 22, 118-134.

17 B. Q. Zou, X. Lu, Q. P. Qin, Y. X. Bai, Y. Zhang, M. Wang, Y. C. Liu, Z. F. Chen and H. Liang, Three novel transition metal complexes of 6-methyl-2-oxo-quinoline-3carbaldehyde thiosemicarbazone: synthesis, crystal structure, cytotoxicity, and mechanism of action, RSC Adv., 2017, 7, 17923-17933.

18 J. A. Choi, J. Y. Kim, J. Y. Lee, C. M. Kang, H. J. Kwon, Y. D. Yoo, T. W. Kim, Y. S. Lee and S. J. Lee, Induction of cell cycle arrest and apoptosis in human breast cancer cells by quercetin, Int. J. Oncol., 2001, 19, 837-844.

19 M. B. Kastan and J. Bartek, Cell-cycle checkpoints and cancer, Nature, 2004, 432, 316-322.

20 S. U. Dighe, S. Khan, I. Soni, P. Jain, S. Shukla, R. Yadav, P. Sen, S. M. Meeran and S. Batra, Synthesis of $\beta$ Carboline-Based N-Heterocyclic Carbenes and Their Antiproliferative and Antimetastatic Activities against Human Breast Cancer Cells, J. Med. Chem., 2015, 58, 34853499.

21 R. Boutros, V. Lobjois and B. Ducommun, CDC25 phosphatases in cancer cells: key players? Good targets?, Nat. Rev. Cancer, 2007, 7, 495-507.

22 F. Belluti, G. Fontana, L. D. Bo, N. Carenini, C. Giommarelli and F. Zunino, Design, synthesis and anticancer activities of stilbene-coumarin hybrid compounds: Identification of novel proapoptotic agents, Bioorg. Med. Chem., 2010, 18, 3543-3550.

23 M. O. Hengartner, The biochemistry of apoptosis, Nature, 2000, 407, 770-776.

24 M. Y. Ye, G. Y. Yao, Y. M. Pan, Z. X. Liao, Y. Zhang and H. S. Wang, Synthesis and antitumor activities of novel $\alpha$ aminophosphonate derivatives containing an alizarin moiety, Eur. J. Med. Chem., 2014, 83, 116-128.
25 R. Martin, J. Carvalho, E. Ibeas, M. Hernández, V. RuizGutierrez and M. Luisa-Nieto, Acidic triterpenes compromise growth and survival of astrocytoma cell lines by regulating reactive oxygen species accumulation, Cancer Res., 2007, 67, 3741-3751.

26 L. Gomez, P. A. Thiebaut, M. Paillard, S. Ducreux, M. Abrial, C. C. D. Silva, A. Durand, M. R. Alam, F. V. Coppenolle, S. S. Sheu and M. Ovize, The SR/ER-mitochondria calcium crosstalk is regulated by GSK3 $\beta$ during reperfusion injury, Cell Death Differ., 2016, 23, 313-322.

27 Y. Tsujimoto, J. Cossman, E. Jaffe and C. M. Croce, Involvement of the bcl-2 gene in human follicular lymphoma, Science, 1985, 228, 1440-1443.

28 D. M. Hockenbery, M. Zutter, W. Hickey, M. Nahm and S. J. Korsmeyer, BCL2 protein is topographically restricted in tissues characterized by apoptotic cell death, Proc. Natl. Acad. Sci. U. S. A., 1991, 88, 6961-6965.

29 S. Qiao, T. Nagasaka, T. Harada and N. Nakashima, p53, Bax and Bcl-2 expression, and apoptosis in gestational trophoblast of complete hydatidiform mole, Placenta, 1998, 19, 361-369.

$30 \mathrm{~K}$. W. Yip and J. C. Reed, Bcl-2 family proteins and cancer, Oncogene, 2008, 27, 6398-6406.

$31 \mathrm{~W}$. A. Siddiqui, A. Ahad and H. Ahsan, The mystery of BCL2 family: Bcl-2 proteins and apoptosis: an update, Arch. Toxicol., 2015, 89, 289-317.

32 S. X. Hua, R. Z. Huang, M. Y. Ye, Y. M. Pan, G. Y. Yao, Y. Zhang and H. S. Wang, Design, synthesis and in vitro evaluation of novel ursolic acid derivatives as potential anticancer agents, Eur. J. Med. Chem., 2015, 95, 435-452.

33 Z. F. Chen, Q. P. Qin, J. L. Qin, Y. C. Liu, K. B. Huang, Y. L. Li, T. Meng, G. H. Zhang, Y. Peng, X. J. Luo and H. Liang, Stabilization of G-quadruplex DNA, inhibition of telomerase activity and tumor cell apoptosis of organoplatinum(II) complexes with oxoisoaporphine, $J$. Med. Chem., 2015, 58, 2159-2179.

34 Y. L. Chu, C. T. Ho, J. G. Chung, R. Raghu, Y. C. Lo and L. Y. Sheen, Allicin induces anti-human liver cancer cells through p53 gene modulating apoptosis and autophagy, $J$. Agric. Food Chem., 2013, 61, 9839-9848. 